September 2008, Vol. 4 No. 2

\title{
PERAN KELOMPOK PETERNAK DALAM MENGEMBANGKAN KEBERDAYAAN PETERNAK SAPI PERAH (KASUS DI KABUPATEN BANDUNG)
}

\section{THE ROLE OF THE DAIRY GROUP FARMERS IN EMPOWERMENT OF DAIRY FARMERS (CASE OF BANDUNG DISTRICT)}

\author{
Unang Yunasaf, Basita Ginting, Margono Slamet, \\ dan Prabowo Tjitropranoto
}

\begin{abstract}
The objective of the research was to study the role of the group farmers especially in term of dynamic of the group farmers, empowerment of the dairy farmers, and their relationship. The sampling population is milk cooperative at Bandung district and target population are the dairy farmers as the members of the cooperative. Sample of research were collected by multistage sampling technique with the result that 4 cooperative and 120 person of dairy farmers. The relationship of the variables were tested by Spearman's rank correlation. The results showed that the group of dairy farmers tend by the cooperative as instrument for improving production of milk of dairy farmers but no facility sufficient so the dairy farmers have empowerment. The dynamic group of farmers was low. The empowerment of dairy farmer was low, especially in the role of dairy farmers as manager and individual of autonomy. There was positive significant correlation between the dynamic group of farmers are empowerment of the dairy farmers.
\end{abstract}

Keywords: the role of the group farmers, the empowerment of dairy farmers.

\section{Pendahuluan}

Sebagian besar peternak sapi perah di Indonesia masih belum mencerminkan sebagai peternak sejati (farmers), sehingga mereka cenderung masih belum berdaya. Dalam kedudukannya sebagai manajer atau pengelola usaha ternak, peternak belum dapat mengambil keputusan yang tepat agar usaha sapi perahnya mencapai hasil atau berkembang sehingga mencapai kelayakan secara ekonomis.

Sampai saat ini usaha sapi perah yang dikelola peternak cenderung tidak berubah dilihat dari tingkat skala usaha atau kepemilikan sapi produktifnya, yang berkisar antara 1-2 ekor. Dalam kedudukannya sebagai pemelihara ternak (cultivator), peternak belum mengetahui, menguasai dan melaksanakan aspek teknis beternak yang baik, sehingga tingkat produksi dan kualitas susu yang dihasilkan sapinya belum optimal. Hal ini menyebabkan produktivitas usaha yang rendah yaitu 9-10 liter/ekor/hari dan produknya berupa susu tidak kompetitif ketika berhadapan dengan susu impor.

Dalam kedudukannya sebagai individu yang otonom, peternak belum dapat bersikap kritis di dalam memperjuangkan hak-haknya khususnya terhadap koperasi, apalagi untuk lebih bersifat independen secara lebih jauh, 
terutama ketika berhadapan dengan pihak Industri Pengolahan Susu.

Ada beberapa faktor yang diduga menghambat terjadinya proses transformasi peternak sapi perah untuk sepenuhnya disebut sebagai farmers. Salah satu faktornya menurut Suradisastra (1999) dan Departemen Pertanian (2002) adalah faktor arus pendekatan pembangunan selama ini yang lebih menempatkan peternak sebagai obyek dan bukan sebagai subyek atau pelaku pembangunan yang memberikan pengaruh tidak berkembangnya para petani termasuk peternak sapi perah. Akibat perencanaan yang bersifat sentralistis dan mekanistis serta seragam menyebabkan petani dan kelembagaannya memiliki ketergantungan yang kuat pada proyek atau program pemerintah. Di sisi lain petani dan kelembagaannya tersebut tidak mempunyai tanggungjawab dalam mengembangkan ideide baru yang lebih sesuai dengan kondisi setempat, sehingga kemandirian petani dan komunitaspun tidak berkembang.

Untuk wilayah Jawa Barat, khususnya di Kabupaten Bandung yang merupakan sentra peternak sapi perah, peran koperasi di dalam membina peternak sapi perah cenderung menurun sebagai akibat menurunnya kinerja organisasi dan usaha koperasi atau koperasinya semakin kurang optimal di dalam menjalankan fungsifungsinya (Asep, dkk. 2005). Indikasi menurunnya peran koperasi di dalam membina peternak sebagai anggotanya diperkuat oleh pernyataan Gubernur Jawa Barat yang menyatakan bahwa koperasi yang ada saat ini sudah mulai menghilangkan triloginya, sehingga keberpihakannya kepada para anggotanyapun semakin berkurang. Untuk itu perlu dicari organ atau elemen lain yang diharapkan dapat menunjang tercapainya keberdayaan dari peternak sapi perah. Dalam hal ini keberadaan kelompok peternak bisa lebih didayagunakan, karena selama ini koperasi pertanian dalam pergerakannya tidak bisa lepas dari pengembangan kelompok tani (Soetrisno, 2001).
Keberadaan kelompok peternak pada koperasi peternak sapi perah belum didayagunakan secara optimal sebagai media yang strategis di dalam memberdayakan peternak yang menjadi anggotanya. Keberadaan kelompok di dalam koperasi dipandang sebagai instrumen di dalam melaksanakan kebijakan organisasi atau sebagai alat untuk tercapainya tujuan organisasi yang belum tentu memberikan manfaat bagi anggota dalam jangka panjang Menurut Chu (1976) kelompok dapat memiliki peran sebagai media transformatif bagi peningkatan kualitas anggotaanggotanya.

Jika kelompok dianggap dapat menjadi media atau wadah peningkatan kualitas peternak sapi perah, sehingga peternak menjadi berdaya maka yang menjadi pertanyaan adalah seberapa besar peran yang dimiliki kelompok untuk itu, khususnya dilihat dari tingkat dinamikanya. Demikian pula layak dipertanyakan bagaimana hubungannya dengan pencapaian keberdayaan dari peternak sapi perah.

Berdasarkan uraian sebelumnya, maka penelitian ini bertujuan mempelajari: (1) peran kelompok khususnya dilihat dari keragaan dinamika kelompok di dalam mendukung berdayanya peternak sapi perah, dan (2) hubungan antara dinamika kelompok peternak dengan keberdayaan peternak sapi perah.

\section{$\underline{\text { Metode Penelitian }}$}

Penelitian menggunakan metode survei yang bersifat deskriptif. Penelitian dilaksanakan dari Oktober 2005 sampai dengan Mei 2006.

Populasi penelitian dibedakan atas populasi sampling dan populasi sasaran (Palte, 1978 diacu Matra dan Kasto, 1989). Populasi sampling adalah koperasi peternak sapi perah yang ada di Kabupaten Bandung dan terdaftar pada GKSI Komda Jawa Barat sebanyak 8 buah. Populasi sasaran adalah seluruh peternak sapi perah anggota dari 
koperasi peternak sapi perah tersebut. Pengambilan sampel penelitian dilakukan melalui teknik pengambilan sampel gugus bertahap (multistage sampling). Sebagai responden adalah peternak anggota koperasi yang terpilih. Langkah-langkah yang dilakukan sehingga dapat memilih sampel responden adalah sebagai berikut:

1. Pemilihan koperasi sebagai sampel pertama terpilih 4 koperasi dari 8 koperasi yang ada, terdiri atas 2 koperasi yang keanggotaanya rata-rata 6624 orang (S1) dan 2 koperasi yang keangggotaannya ratarata 866 orang (S2).

2. Pemilihan TPK (Tempat pelayanan koperasi) atau desa sebagai sampel kedua terpilih 2 TPK dan 2 Desa dari sampel pertama.

3. Pemilihan kelompok peternak sebagai sampel ketiga, terpilih sebanyak 8 kelompok dari sampel kedua.

4. Pemilihan peternak sebagai responden sebanyak 120 peternak dari sampel ketiga.

Peubah yang ditelaah meliputi dinamika kelompok sebagai peubah bebas dan keberdayaan peternak sapi perah sebagai variabel terikat.
Cara pengukuran untuk kedua peubah dilakukan dengan skala ordinal dalam bentuk indeks. Dalam menentukan kriteria atau kelas kategori dari peubah dinamika kelompok dan keberdayaan peternak didasarkan atas perhitungan selisih antara skor harapan maksimum tertinggi dan skor harapan maksimum terendah, yang dibagi menjadi lima dengan selang kelas yang sama, sehingga diperoleh ketegori sangat rendah, rendah, cukup atau sedang, tinggi dan sangat tinggi.

Untuk melihat perbedaan keragaan tiap peubah yang diteliti antar strata diuji dengan uji Mann-Whitney, sedang uji keeratan yang digunakan untuk mengukur hubungan peubah adalah analisis korelasi peringkat Spearman.

\section{$\underline{\text { Hasil dan Pembahasan }}$}

\section{$\underline{\text { Keadaan Umum Kelompok Contoh }}$}

Sesuai dengan fokus penelitian pada kelompok peternak, maka keadaan umum kelompok peternak sapi perah contoh disajikan pada Tabel 1.

Tabel 1. Keadaan Umum Kelompok Peternak Sapi Perah Contoh

\begin{tabular}{|c|c|c|c|c|c|}
\hline \multirow[t]{3}{*}{ No. } & Uraian & Alamat & $\begin{array}{l}\text { Lama Berdiri } \\
\text { (Thn) }\end{array}$ & $\begin{array}{c}\text { Jumlah Anggota } \\
\text { (Orang) }\end{array}$ & $\begin{array}{c}\text { Jumlah Sapi } \\
\text { (Ekor) }\end{array}$ \\
\hline & Starta 1 & & & & \\
\hline & KPBS: & & & & \\
\hline 1. & Kel. Babakan Kiara 07 & Desa Pulosari & 30 & 22 & 75 \\
\hline \multirow[t]{2}{*}{2.} & Kel. Babakan Kiara 09 & Desa Margamekar & 19 & 29 & 99 \\
\hline & KPSBU: & & & & \\
\hline 3. & Kel. Karamat 30 & Desa Cikahuripan & 27 & 33 & 142 \\
\hline \multirow[t]{4}{*}{4.} & Kel. Karamat 31 & Desa Cikahuripan & 20 & 40 & 170 \\
\hline & $\begin{array}{l}\text { Kisaran } \\
\text { Rataan }\end{array}$ & & $\begin{array}{c}19-30 \\
24\end{array}$ & $\begin{array}{c}22-40 \\
31\end{array}$ & $\begin{array}{c}75-170 \\
121\end{array}$ \\
\hline & Strata 2 & & & & \\
\hline & KUD Mitra Usaha: & & & & \\
\hline 5. & Kel. Cidulang & Desa Pingggirsari & 10 & 45 & 118 \\
\hline \multirow[t]{2}{*}{6.} & Kel. Mekarsari & Desa Pinggirsari & 3 & 31 & 65 \\
\hline & KUD Sinarjaya: & & & & \\
\hline 7. & Kel. Pasir Angin & Desa Cilengkrang & 24 & 48 & 238 \\
\hline \multirow[t]{4}{*}{8.} & Kel. Cipulus & Desa Cilengkrang & 24 & 38 & 181 \\
\hline & $\begin{array}{l}\text { Kisaran } \\
\text { Ratan }\end{array}$ & & $\begin{array}{c}3-24 \\
15\end{array}$ & $\begin{array}{c}31-48 \\
40,5\end{array}$ & $\begin{array}{c}65-238 \\
150\end{array}$ \\
\hline & Kisaran Total & - & $3-30$ & $22-45$ & $65-238$ \\
\hline & Rataan Total & & 19,62 & 36 & 136 \\
\hline
\end{tabular}


Keberadaan kelompok-kelompok contoh sampai saat ini lebih dominan sebagai wadah yang fungsi utamanya untuk melaksanakan dan menyelesaikan tugas-tugas yang diberikan oleh koperasi, khususnya untuk mempermudah penyampaian sarana produksi, dan penampungan susu dari peternak.

\section{Dinamika Kelompok $\underline{\text { Peternak Sapi Perah }}$}

Dinamika kelompok peternak sapi perah adalah gerak dari kelompok peternak tersebut yang disebabkan oleh segala kekuatan yang terdapat dalam kelompok yang menentukan atau mempengaruhi perilaku kelompok dan anggota-anggotanya dalam rangka pencapaian tujuan secara efektif.
Dinamika kelompok ini diukur dengan cara mengetahui jumlah skor dari tujuh komponen indikatornya, yang meliputi: (1) kepemimpinan ketua kelompok, (2) tujuan kelompok, (3) struktur kelompok,(4) fungsi tugas kelompok, (5) pembinaan dan pemeliharaan kelompok, (6) kekompakan kelompok, dan (7) suasana kelompok, (8) tekanan kelompok, dan (9) efektivitas kelompok.

Dinamika kelompok peternak sapi perah, rata-rata tergolong rendah $(41,31$ persen). Terdapat perbedaan nyata antar strata, yaitu tingkat dinamika kelompok pada strata 1 lebih baik dibandingkan pada strata 2 . Pada kelompok di strata 1 unsur-unsur dinamika kelompoknya lebih dinamis dibandingkan pada kelompok strata 2, terutama dalam struktur kelompok, fungsi tugas kelompok, pembinaan dan pemeliharaan kelompok, serta suasana kelompok, tekanan kelompok dan efektivitas kelompok (lihat Tabel 2).

Tabel 2. Keragaan Dinamika Kelompok Peternak Sapi Perah

\begin{tabular}{|l|l|c|c|c|}
\hline \multirow{2}{*}{ No. } & \multicolumn{1}{|c|}{ Uraian } & Strata 1 & Strata 2 & Total \\
\cline { 3 - 5 } & & Skor $^{\mathbf{1}}$ & Skor $^{\mathbf{1}}$ & Skor $^{\mathbf{1}}$ \\
\hline 1. & Kepemimpinan & 39,62 & 38,46 & 39,23 \\
\hline 2. & Tujuan Kelompok & 39,17 & 36,67 & 38,33 \\
\hline 3. & Struktur Kelompok & $40,00^{*}$ & 36,35 & 37,50 \\
\hline 4. & Fungsi Tugas Kelompok & $45,46^{*}$ & 38,18 & 41,82 \\
\hline 5. & Pembinaan dan & $44,29^{*}$ & 41,43 & 42,86 \\
\hline 6. & Pemeliharaan Kelompok & & & 38,75 \\
\hline 7. & Suasana Kelompok & 40,00 & 37,50 & 42,50 \\
\hline 8. & Tekanan Kelompok & $47,50^{*}$ & 37,50 & 45,00 \\
\hline 9. & Efektivitas Kelompok & $50,00^{*}$ & 37,50 & 48,00 \\
\hline 10. & Dinamika Kelompok & $50,00^{*}$ & 44,00 & 41,31 \\
\hline
\end{tabular}

\section{Keterangan:}

Strata 1 : Koperasi yang jumlah anggotanya rata-rata 6624 orang

Strata 2 : Koperasi yang jumlah anggotanya rata-rata 866 orang

${ }^{1)}$ Skor rata-rata posisi atau median (dalam prosentase dari skor harapan maksimum)

* Berdasarkan hasil uji Mann-Whitney, nyata pada $\alpha=0,05$

Kelas kategori:

(SR) Sangat rendah: skor $<36 \%$ dari skor harapan maksimum

(R) Rendah $\quad$ : $36 \% \leq$ skor $<52 \%$ dari skor harapan maksimum

(C) Cukup : $\quad 52 \% \leq$ skor $<68 \%$ dari skor harapan maksimum

(T) Tinggi : : $68 \% \leq$ skor $<84 \%$ dari skor harapan maksimum

(ST) Sangat tinggi : skor $\geq 84 \%$ dari skor harapan maksimum 
Dinamika kelompok peternak sapi perah rata-rata tergolong rendah, terlihat dari masih rendahnya faktor-faktor atau kekuatan yang mampu menggerakkan perilaku kelompok dan anggota-anggota untuk mencapai tujuannya secara efektif.

Lemahnya unsur-unsur dari dinamika kelompok peternak ini tercermin dari: (1) masih rendahnya tingkat kepemimpinan ketua kelompok ; (2) tidak adanya tujuan yang spesifik yang muncul dari kelompok, karena tujuan dan latar belakang berdirinya kelompok tidak lepas sebagai bagian dari kebijakan koperasi untuk mempermudah pembinaan dan pelayanan koperasi kepada peternak anggota yang ada di wilayah kerjanya; (3) terbatasnya struktur kekuasaan atau kewenangan, umumnya kelompok hanya dikendalikan oleh seorang ketuanya saja, karenanya dalam pengaturan tugas dan komunikasipun semuanya bertumpu pada ketua kelompok; (4) pelaksanaan fungsi tugas kelompok, yang bersumber langsung dari insiatif kelompok tergolong jarang, lebih banyak dipengaruhi oleh berjalan tidaknya kegiatan pembinaan dan pelayanan dari koperasi; (5) belum adanya usaha-usaha yang spesifik yang berasal dari kelompok untuk menjaga kehidupannya, tetapi biasanya terkait langsung dengan kegiatan koperasi; (6) rasa keterikatan anggota terhadap kelompok umumnya hanya sebatas sebagai bagian dari keanggotaan di koperasi, yang dihimpun dalam kelompok; (7) interaksi antar anggota belum merupakan bagian dari interaksi yang bersifat substantif, umumnya hanya berkisar sebagai bagian dari rutinitas sehari-hari belum belum didasarkan atas adanya kesadaran kepemilikan identitas sosial yang kuat; dan (8) kurangnya tuntutan dari anggota agar kelompok dapat dikelola lebih baik lagi dan tekanan dari luar khususnya dari koperasi hanya berorientasi agar kelompok berfungsi sebagai penyalur sarana produksi dan menghimpun sementara susu peternak.

\section{$\underline{\text { Keberdayaan Peternak Sapi Perah }}$}

Keberdayaan peternak sapi perah adalah tingkat berkembangnya potensi peternak dalam perannya sebagai manajer usahatani, pemelihara ternak dan individu yang otonom. Hasil penelitian pada Tabel 3 menunjukkan bahwa keberdayaan peternak sapi perah, rata-rata tergolong rendah $(50,67$ persen). Terdapat perbedaan yang nyata antar strata, yaitu pada strata 1 tingkat keberdaanyaan peternaknya relatif lebih tinggi dibandingkan dengan pada strata 2 , khususnya dilihat dari keberdayaan peternak dalam perannya sebagai pemelihara ternak dan individu yang otonom.

Para peternak umumnya belum dapat menunjukkan keberdayaannya, terutama dalam perannya sebagai manajer dan sebagai individu yang otonom. Peternak sebagai seorang manajer, idealnya dapat melakukan pengambilan keputusan yang tepat agar usaha sapi perahnya mencapai keberhasilan atau semakin berkembang. Pada kenyataannya usaha sapi perah yang dikelola para peternak, kondisinya dari tahun ke tahun cenderung tidak berubah.

Tabel 3. Keragaan Keberdayaan Peternak Sapi Perah

\begin{tabular}{|l|l|c|c|c|}
\hline \multirow{2}{*}{ No. } & \multicolumn{1}{|c|}{ Uraian } & Strata 1 & Strata 2 & Total \\
\cline { 3 - 5 } & & Skor rataan $^{\text {1) }}$ & Skor rataan $^{\text {1) }}$ & Skor rataan $^{\text {1) }}$ \\
\hline 1. & $\begin{array}{l}\text { Keberdayaan sebagai } \\
\text { Manajer }\end{array}$ & 44,62 & 40,00 & 41,54 \\
\hline 2. & $\begin{array}{l}\text { Keberdayaan sebagai } \\
\text { Pemelihara Ternak }\end{array}$ & $64,42^{*}$ & 52,73 & 57,88 \\
\hline 3. & $\begin{array}{l}\text { Keberdayaan sebagai } \\
\text { Individu Otonom }\end{array}$ & $52,86^{*}$ & 42,14 & 44,29 \\
\hline 4. & Keberdayaan Peternak & $57,00^{*}$ & 47,00 & 50,67 \\
\hline
\end{tabular}

Keterangan: seperti pada Tabel 2 
Dengan pengalamannya beternak sapi perah yang sudah rata-rata di atas 10 tahunan, ternyata tingkat pemilikan sapi perahnya masih tetap rendah, umumnya mereka memiliki 2 ekoran sapi produktif. Tingkat kepemilikan ternak seperti ini masih jauh untuk dicapainya kelayakan usaha sapi perah, yaitu dengan skala pemilikan 10-15 ekor atau rata-rata 7-8 ekor sapi laktasi. Belum berkembangnya potensi peternak dalam perannya sebagai manajer ini, terlihat dari masih rendahnya peternak di dalam melakukan: (1) perincian terhadap tujuan usahanya, (3) penyusunan prioritas pengembangan usaha, dan (3) pengembangan belajar. Kesemuanya ini menggambarkan pula rendahnya motivasi peternak untuk mencapai keberhasilan usahanya, karena masih rendahnya kesadaran akan kebutuhan pencapaian hasil yang lebih baik dari usahanya.

Dalam perannya sebagai individu otonom, yakni peternak dapat menggunakan hak-haknya, dan ketidaktergantungannya khususnya terhadap koperasi, juga tergolong rendah. Kecuali sebagian peternak di strata 1, umumnya para peternak belum memahami hak-haknya sebagai anggota koperasinya secara lengkap. Peternak umumnya mengetahui haknya sebatas dalam mendapatkan pelayanan, dan mendapatkan SHU, dan menghadiri RAT.

Terhadap beberapa haknya yang diketahui itupun, belum diupayakan untuk digunakan dengan sebaik-baiknya. Seperti dikemukakan Ropke (2003) pengenalan akan hak-hak sebagai anggota koperasi secara utuh dan sekaligus menggunakan hak-haknya tersebut merupakan bagian penting di dalam mengontrol dan mengendalikan koperasi agar berpihak pada kepentingan anggota. Para peternakpun tidak bisa leluasa atau memiliki alternatif di dalam memenuhi kebutuhan sarana produksi, khususnya pakan konsentrat, dan di dalam menjual susunya selain ke koperasi, karena kalau tidak melakukannya ke koperasi akan kena sanksi dikeluarkan. Sejauh inipun para peternak belum bisa berbuat lebih jauh, jika berhadapan dengan tingkat pelayanan dari koperasi yang jelek seperti yang dijumpai pada strata 2 .

Dalam aspek teknis beternak sapi perah, umumnya peternak sudah cukup melaksanakannya, walaupun belum optimal. Peternak relatif tahu dan telah melaksanakan beberapa hal yang umum, yang perlu diperhatikan di dalam melaksanakan tatalaksana budidaya sapi perah. Hal yang membedakan kinerja peternak dalam melaksanakan aspek teknis budidaya ini antar satu koperasi dengan koperasi lainnya yang cukup menonjol adalah di dalam penanganan agar diperoleh susu yang berkualitas. Para peternak sapi perah, dari strata 1 relatif sudah lebih baik di dalam penanganan hal tersebut dibanding dengan peternak dari strata 2 . Susu yang dihasilkan peternak tersebut tergolong relatif lebih baik dilihat dari segi kualitas

\section{Hubungan Dinamika Kelompok Peternak dengan Keberdayaan Peternak Sapi Perah}

Hasil uji korelasi rank Spearman hubungan antara indikator-indikator dinamika kelompok peternak dan keberdayaan peternak ditampilkan pada Tabel 4.

Tabel 4. Nilai koefisien Korelasi rank Spearman Hubungan Dinamika Kelompok Peternak dengan Keberdayaan Peternak Sapi Perah

\begin{tabular}{|l|l|c|}
\hline No. & \multicolumn{1}{|c|}{ Uraian } & $\mathbf{r}_{\mathbf{s}}$ \\
\hline 1. & Kepemimpinan ketua kelompok & $0,466^{* *}$ \\
\hline 2. & Tujuan kelompok & $0,507^{* *}$ \\
\hline 3. & Struktur kelompok & $0,602^{* *}$ \\
\hline 4. & Fungsi tugas kelompok & $0,552^{* *}$ \\
\hline 5. & Pembinaan dan pemeliharaan kelompok & $0,569^{* *}$ \\
\hline 6. & Kekompakan kelompok & $0,483^{* *}$ \\
\hline 7. & Suasana kelompok & $0,525^{* *}$ \\
\hline 8. & Tekanan kelompok & $0,315^{* *}$ \\
\hline 9. & Efektivitas kelompok & $0,400^{* *}$ \\
\hline
\end{tabular}

Keterangan: ** Nyata pada $\alpha=0,01$ 
Dari hasil analisis uji korelasi rank Spearman hubungan indikator-indikator dinamika kelompok peternak dengan keberdayaan peternak sapi perah sebagaimana pada Tabel 4 semuanya menunjukkan hubungan yang sangat nyata. Hal ini berarti bahwa tinggi rendahnya keberdayaan peternak sapi perah berhubungan dengan tinggi rendahnya dinamika kelompok peternak.

\section{$\underline{\text { Kesimpulan }}$}

(1) Keragaan dinamika kelompok peternak dan keberdayaan peternak sapi perah, pada koperasi strata 1 relatif lebih baik dibandingkan pada koperasi strata 2.

(2) Kelompok peternak sapi perah masih cenderung diposisikan sebagai alat dari koperasi di dalam mendorong peternak untuk meningkatkan produksi susunya tanpa disertai fasilitasi dalam mendayagunakan fungsi kelompok agar peternak memiliki keberdayaan.

(3) Keragaan dinamika kelompok peternak sapi perah masih relatif rendah. Hal ini ditunjukkan oleh kepemimpinan ketua kelompok yang belum efektif, tidak adanya tujuan yang spesifik yang muncul dari kelompok, terbatasnya struktur kekuasaan atau kewenangan dari kelompok, pelaksanaan fungsi tugas kelompok yang bersumber langsung dari inisatif kelompok relatif jarang, belum adanya usaha-usaha yang spesifik di dalam menjaga kehidupan kelompok, rasa keterikatan anggota terhadap kelompok sebatas sebagai bagian dari keanggotaan di koperasi, interaksi antar anggota di kelompok belum merupakan bagian dari interaksi yang bersifat substantif, belum memadainya tekanan pada kelompok, dan belum efektifnya kelompok.

(4) Keragaan keberdayaan peternak sapi perah masih relatif rendah, terutama di dalam perannya sebagai manajer dan individu yang otonom.
(5) Terdapat hubungan yang sangat nyata antara dinamika kelompok peternak dengan keberdayaan peternak sapi perah.

\section{$\underline{\text { Rujukan }}$}

Asep S., T. Toto dan S. Cece. 2005. Proposal Pra Rusnas Pengembangan Sapi Perah Indonesia Berbasis Sumberdaya Lokal.Centras, Institut Pertanian Bogor, Bogor.

Chu, G.D. 1976. Groups and Development. Dalam: Communication for Group Transformation in Developmen. Editor Chu, G.D., S. Rahim, dan D.L. Kincain. Hawai: East West Center East West Communication Institut.

Departemen Pertanian. 2000. Kebijakan Pemberdayaan Kelembagaan Tani. Jakarta: Biro Perencanaan dan KLN Departemen Pertanian.

Matra, IB., dan Kasto. 1989. Penentuan Sampel. Dalam:Metode Penelitian Survai. Diedit M. Singarimbun dan S. Effendi. LP3ES, Jakarta.

Ropke, J. 2003. Ekonomi Koperasi:Teori dan Manajemen. Salemba Empat, Jakarta.

Suradisastra, K. 1999. Rangkuman dan Arah Penelitian Kelembagaan dan Organisasi Pertanian. Dalam Dinamika Inovasi Sosial Ekonomi dan Kelembagaan Pertanian. PPSEP. Badan Penelitian dan Pengembangan Pertanian. Jakarta: Departemen Pertanian.

Soetrisno, N. 2003. Koperasi Indonesia: Potret dan Tantangan. Dalam: Kumpulan__Artikel Usaha Kecil Menengah dan Koperasi. Disusun Marwan. Program Magister Sain Pascasarjana Universitas Padjadjaran. 